\title{
Triggering of Suicidal Erythrocyte Death by Gefitinib
}

\author{
Abdulla Al Mamun Bhuyan ${ }^{\mathrm{a}}$ Teresa Wagner ${ }^{\mathrm{a}}$ Hang Cao ${ }^{\mathrm{a}}$ Florian Lang ${ }^{\mathrm{a}, \mathrm{b}}$ \\ ${ }^{a}$ Department of Internal Medicine III, Eberhard-Karls-University of Tuebingen, Tuebingen, ${ }^{b}$ Department \\ of Molecular Medicine II, Medical Faculty, Heinrich Heine University, Duesseldorf, Germany
}

\section{Key Words}

Phosphatidylserine • Eryptosis • Oxidative stress $•$ Calcium

\begin{abstract}
Background/Aims: The epidermal growth factor receptor-tyrosine kinase inhibitor gefitinib is effective against several malignancies and is mainly utilized in the treatment of epidermal growth factor receptor mutation positive non-small cell lung cancer. The anti-cancer effect of the drug involves stimulation of apoptosis. Side effects of gefitinib include anemia. At least in theory, the development of anemia during gefitinib treatment could result from triggering of eryptosis, the suicidal erythrocyte death characterized by cell shrinkage and by cell membrane scrambling with phosphatidylserine translocation to the erythrocyte surface. Signaling potentially stimulating eryptosis include increase of cytosolic $\mathrm{Ca}^{2+}$ activity $\left(\left[\mathrm{Ca}^{2+}\right]_{i}\right)$ and generation of oxidative stress. The present study explored, whether gefitinib stimulates eryptosis and, if so, whether its effect involves $\mathrm{Ca}^{2+}$ entry and/or oxidative stress. Methods: Flow cytometry was employed to quantify cell volume from forward scatter, phosphatidylserine exposure at the cell surface from annexin-V-binding, $\left[\mathrm{Ca}^{2+}\right]_{\mathrm{i}}$ from Fluo3-fluorescence, and reactive oxygen species (ROS) abundance from 2',7'-dichlorodihydrofluorescein diacetate (DCFDA) dependent fluorescence. Results: A 48 hours exposure of human erythrocytes to gefitinib ( $\geq 2 \mu \mathrm{g} / \mathrm{ml}$ ) significantly decreased forward scatter and significantly increased the percentage of annexinV-binding cells. Gefitinib did not significantly increase Fluo3-fluorescence but the effect of gefitinib on annexin-V-binding was significantly blunted by removal of extracellular $\mathrm{Ca}^{2+}$. Gefitinib further significantly increased DCFDA fluorescence. Conclusions: Gefitinib triggers erythrocyte shrinkage and phospholipid scrambling of the erythrocyte cell membrane, an effect at least in part dependent on extracellular $\mathrm{Ca}^{2+}$ and paralleled by oxidative stress.

\section{Introduction}

The epidermal growth factor receptor-tyrosine kinase inhibitor (EGFR-TKI) gefitinib [1] is used for the treatment of non-small cell lung cancer carrying an epidermal growth factor receptor mutation [1-35]. Gefitinib has further been shown to be effective in other malignancies [36], such as other lung cancers [37], breast cancer [38], squamous cell carcinoma [36], and colorectal cancer [36]. Moreover, gefitinib has been used in ectopic

Florian Lang

KARGER
Department of Internal Medicine III, University of Tuebingen,

Gmelinstr. 5, 72076 Tuebingen (Germany)

Tel. +49 7071 29-72194, Fax +49 7071 29-5618, E-Mail florian.lang@uni-tuebingen.de 


\section{Cellular Physiology Cell Physiol Biochem 2017;41:1697-1708

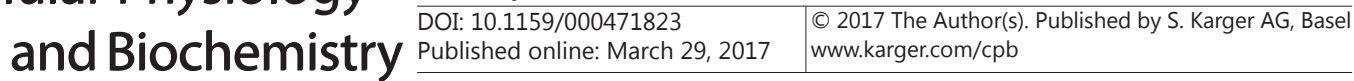

Al Mamun Bhuyan et al.: Gefitinib-Induced Eryptosis

pregnancy [39]. Gefitinib is effective against malignancy at least in part by triggering suicidal death or apoptosis of tumor cells [40-43].

Side effects of gefitinib may include anemia [44-49]. In theory, the anemia could result from suicidal death of erythrocytes or eryptosis [50]. Hallmarks of eryptosis are cell shrinkage [51] and breakdown of phosphatidylserine asymmetry of the cell membrane with phosphatidylserine translocation to the erythrocyte surface [50]. Signaling contributing to the orchestration of eryptosis include increase of cytosolic $\mathrm{Ca}^{2+}$ activity $\left(\left[\mathrm{Ca}^{2+}\right]_{\mathrm{i}}\right)[50]$, ceramide [52], caspases [50, 53, 54], G-protein Galphai2 [55], casein kinase 1 $\alpha$ [50], Janus-activated kinase JAK3 [50], protein kinase C [50], and p38 kinase [50]. Inhibitors of eryptosis include AMP activated kinase AMPK [50], cGMP-dependent protein kinase [50], mitogen and stress activated kinase MSK1/2 [56], PAK2 kinase [50] and sorafenib/sunitinib sensitive kinases [50]. Eryptosis is stimulated by hyperosmotic shock [50], oxidative stress [50], energy depletion [50], or a myriad of xenobiotics [50, 57-115]. Augmented eryptosis is observed in several clinical conditions including iron deficiency [50], dehydration [116], hyperphosphatemia [117], chronic kidney disease (CKD) [118-121], hemolytic-uremic syndrome [122], diabetes [123], hepatic failure [57], malignancy [124, 125], arteriitis [126], sepsis [127], sickle-cell disease [50], beta-thalassemia [50], Hb-C and G6PD-deficiency [50], Wilsons disease [127], as well as advanced age [128]. Eryptosis further increases during storage of blood for transfusion [129].

The presentstudy explored, whether gefitinib could trigger eryptosis, which would provide an explanation for gefitinib induced anemia. To this end, human erythrocytes from healthy volunteers were exposed to gefitinib and the hallmarks of eryptosis, phosphatidylserine surface abundance and cell volume determined by flow cytometry. In order to shed light on the underlying signaling $\left[\mathrm{Ca}^{2+}\right]_{i}$, and formation of reactive oxygen species (ROS) were determined by flow cytometry.

\section{Materials and Methods}

\section{Erythrocytes, solutions and chemicals}

Fresh Li-Heparin-anticoagulated blood samples were kindly provided by the blood bank of the University of Tübingen. The study is approved by the ethics committee of the University of Tübingen (184/2003 V). The blood was centrifuged at $120 \mathrm{~g}$ for $20 \mathrm{~min}$ at $21^{\circ} \mathrm{C}$ and the platelets and leukocytes-containing supernatant was disposed. Erythrocytes were incubated in vitro at a hematocrit of $0.4 \%$ in Ringer solution containing (in $\mathrm{mM}$ ) $125 \mathrm{NaCl}, 5 \mathrm{KCl}, 1 \mathrm{MgSO}_{4}, 32 \mathrm{~N}$-2-hydroxyethylpiperazine-N-2-ethanesulfonic acid (HEPES; pH 7.4), 5 glucose, 1 $\mathrm{CaCl}_{2}$, at $37^{\circ} \mathrm{C}$ for 48 hours. Where indicated, erythrocytes were exposed for 48 hours to gefitinib (Sigma Aldrich, Hamburg, Germany). In order to estimate the impact of $\mathrm{Ca}^{2+}$ entry on gefitinib induced eryptosis, erythrocytes were exposed to gefitinib in the presence and absence of extracellular $\mathrm{Ca}^{2+}$.

Annexin-V-binding and forward scatter

After incubation under the respective experimental condition, a $150 \mu \mathrm{l}$ cell suspension was washed in Ringer solution containing $5 \mathrm{mM} \mathrm{CaCl}_{2}$ and then stained with Annexin-V-FITC (1:200 dilution; ImmunoTools, Friesoythe, Germany) in this solution at $37^{\circ} \mathrm{C}$ for $15 \mathrm{~min}$ under protection from light. The annexin-Vabundance at the erythrocyte surface was subsequently determined on a FACS Calibur (BD, Heidelberg, Germany). Annexin-V-binding was measured with an excitation wavelength of $488 \mathrm{~nm}$ and an emission wavelength of $530 \mathrm{~nm}$. A marker (M1) was placed to set an arbitrary threshold between annexin-V-binding cells and control cells. The same threshold was used for untreated and gefitinib treated erythrocytes. A dot plot of forward scatter (FSC) vs. side scatter (SSC) was set to linear scale for both parameters. The threshold of forward scatter was set at the default value of " 52 ".

Intracellular $\mathrm{Ca}^{2+}$

After incubation, erythrocytes were washed in Ringer solution and loaded with Fluo-3/AM (Biotium, Hayward, USA) in Ringer solution containing $5 \mathrm{mM} \mathrm{CaCl}_{2}$ and $5 \mu \mathrm{M}$ Fluo-3/AM. The cells were incubated at $37^{\circ} \mathrm{C}$ for $30 \mathrm{~min} . \mathrm{Ca}^{2+}$-dependent fluorescence intensity was measured with an excitation wavelength 
of $488 \mathrm{~nm}$ and an emission wavelength of $530 \mathrm{~nm}$ on a FACS Calibur. Afterwards, the geomean of the $\mathrm{Ca}^{2+}$ dependent fluorescence was determined.

Reactive oxygen species (ROS)

Oxidative stress was determined utilizing 2',7'-dichlorodihydrofluorescein diacetate (DCFDA). After incubation, a $150 \mu$ l suspension of erythrocytes was washed in Ringer solution and stained with DCFDA (Sigma, Aldrich, Germany) in Ringer solution containing DCFDA at a final concentration of $10 \mu \mathrm{M}$. Erythrocytes were incubated at $37^{\circ} \mathrm{C}$ for $30 \mathrm{~min}$ in the dark and washed two times in Ringer solution. The DCFDA-loaded erythrocytes were resuspended in $200 \mu$ l Ringer solution and ROS-dependent fluorescence intensity was measured at an excitation wavelength of $488 \mathrm{~nm}$ and an emission wavelength of $530 \mathrm{~nm}$ on a FACS Calibur (BD). Subsequently, the geomean of the DCFDA dependent fluorescence was determined.

\section{Statistics}

Data are expressed as arithmetic means \pm SEM. As indicated in the figure legends, statistical analysis was made using ANOVA with Tukey's test as post-test and $t$ test as appropriate. $\mathrm{n}$ denotes the number of different erythrocyte specimens studied. Since different erythrocyte specimens used in distinct experiments are differently susceptible to triggers of eryptosis, the same erythrocyte specimens have been used for control and experimental conditions.

\section{Results}

Effect of gefitinib on cell volume and cell membrane scrambling

The present study tested the effect of gefitinib on eryptosis, the suicidal erythrocyte death. Hallmarks of eryptosis include cell shrinkage and phospholipid scrambling of the cell membrane with phosphatidylserine translocation to the cell surface.

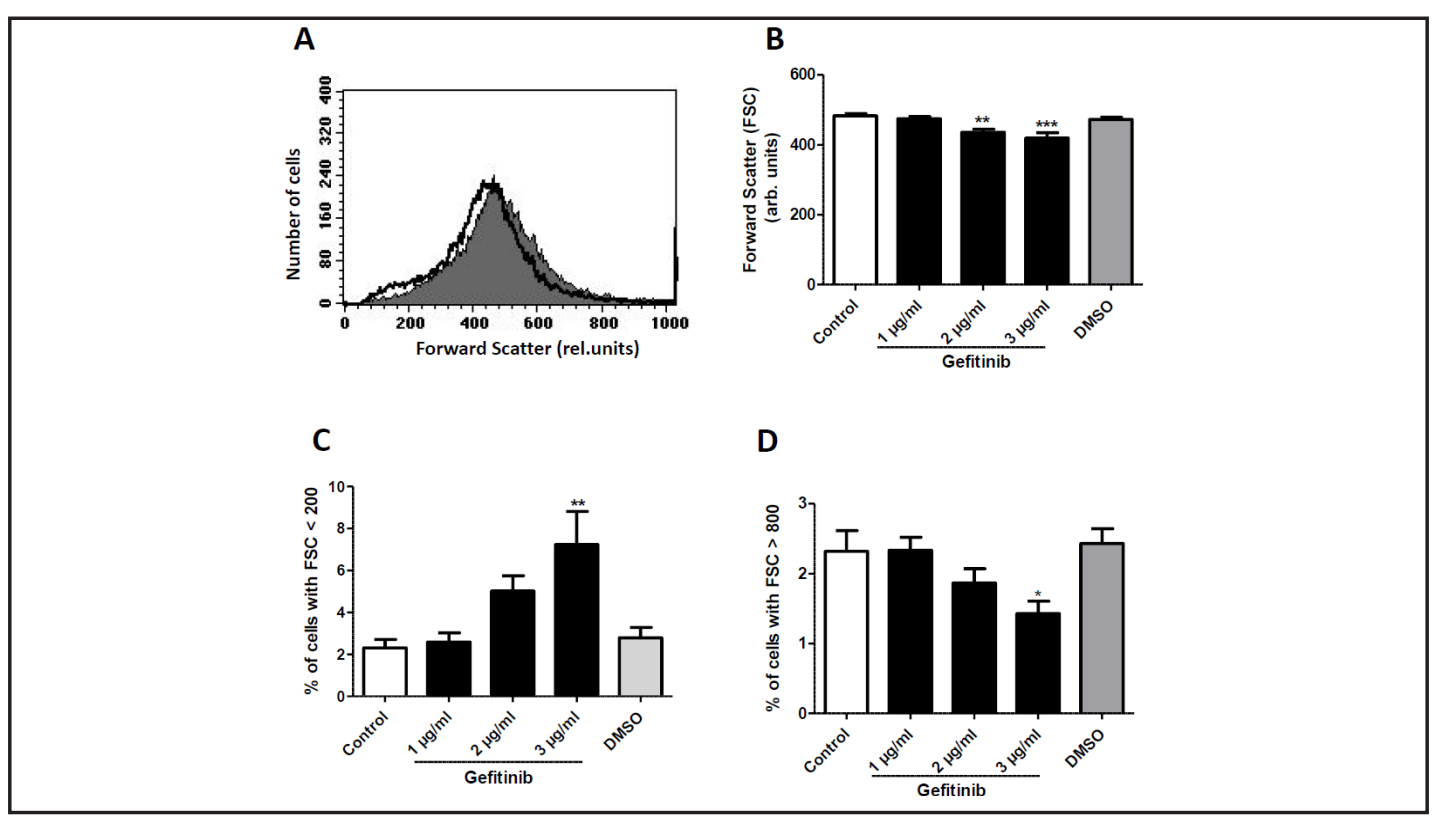

Fig. 1. Effect of gefitinib on erythrocyte forward scatter. A. Original histograms of forward scatter of erythrocytes following exposure for 48 hours to Ringer solution without (grey area) and with (black line) presence of $3 \mu \mathrm{g} / \mathrm{ml}$ gefitinib. B. Arithmetic means \pm SEM ( $\mathrm{n}=17$ ) of the erythrocyte forward scatter (FSC) following incubation for 48 hours to Ringer solution without (white bar) or with (black bars) gefitinib (1 - $3 \mu \mathrm{g}$ ) or solvant DMSO alone (grey bar). C,D. Arithmetic means \pm SEM of the percentage of erythrocytes with (C) FSC $<200$ or (D) FSC $>800$ following incubation for 48 hours to Ringer solution without (white bar) or with (black bars) gefitinib $(1-3 \mu \mathrm{g} / \mathrm{ml})$ or solvant DMSO alone (grey bar). ${ }^{*}(\mathrm{P}<0.05),{ }^{* *}(\mathrm{p}<0.01),{ }^{* * *}(\mathrm{p}<0.001)$ indicates significant difference from the absence of gefitinib (ANOVA). 


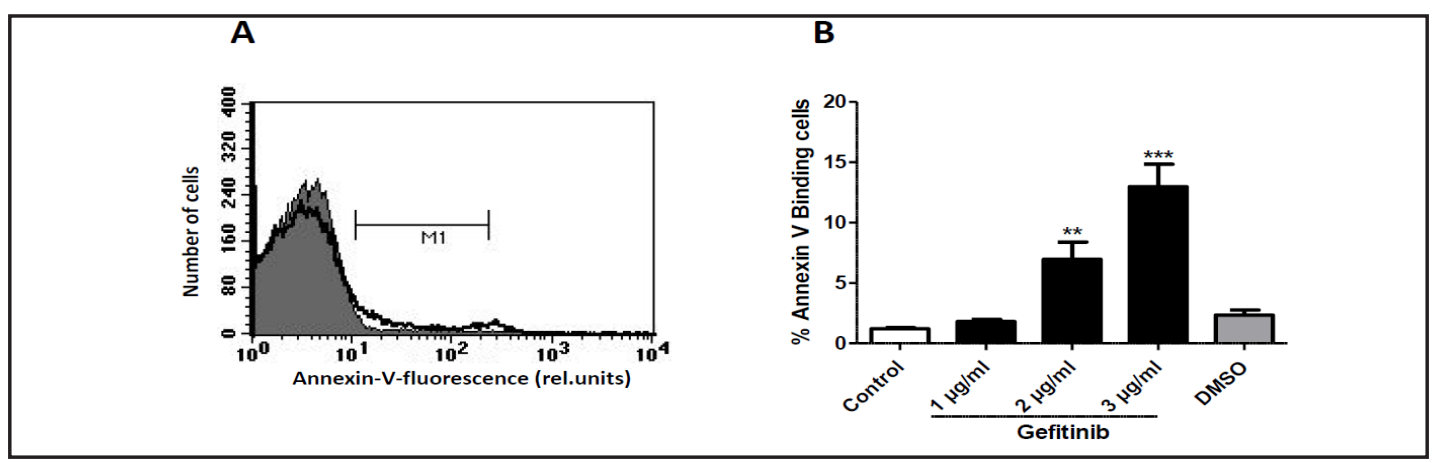

Fig. 2. Effect of gefitinib on phosphatidylserine exposure. A. Original histogram of annexin-V-binding of erythrocytes following exposure for 48 hours to Ringer solution without (grey area) and with (black line) presence of $3 \mu \mathrm{g} / \mathrm{ml}$ gefitinib. B. Arithmetic means \pm SEM ( $=17)$ of erythrocyte annexin-V-binding following incubation for 48 hours to Ringer solution without (white bar) or with (black bars) gefitinib (1 - $3 \mu \mathrm{g} /$ $\mathrm{ml})$. For comparison, the effect of the solvent DMSO is shown (grey bar). ${ }^{* *}(\mathrm{p}<0.01),{ }^{* * *}(\mathrm{p}<0.001)$ indicates significant difference from the absence of gefitinib (ANOVA).

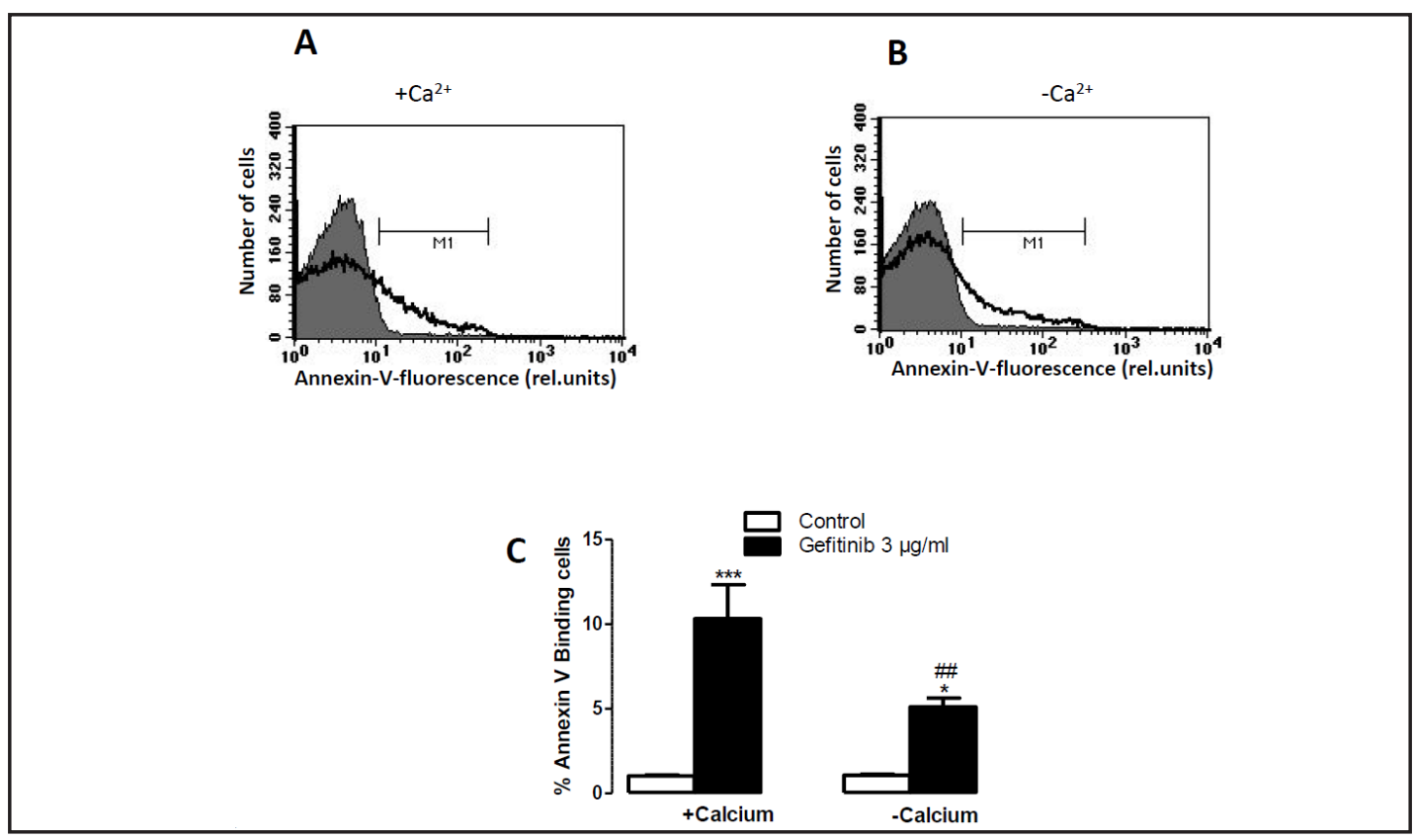

Fig. 3. $\mathrm{Ca}^{2+}$ sensitivity of gefitinib-induced phosphatidylserine exposure. A,B. Original histograms of annexin-V-binding of erythrocytes following exposure for 48 hours to Ringer solution without (grey areas) and with (black lines) gefitinib ( $3 \mu \mathrm{g} / \mathrm{ml}$ ) in the presence (A) and absence (B) of extracellular $\mathrm{Ca}^{2+}$. C. Arithmetic means \pm SEM $(n=13)$ of annexin-V-binding of erythrocytes after a 48 hours treatment with Ringer solution without (white bars) or with (black bars) gefitinib $(3 \mu \mathrm{g} / \mathrm{ml})$ in the presence (left bars, $\left.+\mathrm{Ca}^{2+}\right)$ and absence (right bars, $\left.-\mathrm{Ca}^{2+}\right)$ of $\mathrm{Ca}^{2+} .{ }^{*}(\mathrm{p}<0.05),{ }^{* * *}(\mathrm{p}<0.001)$ indicates significant difference from the absence of gefitinib, \#\#(p<0.01) indicates significant difference from the presence of $\mathrm{Ca}^{2+}$ (ANOVA).

As a measure of erythrocyte volume forward scatter was determined utilizing flow cytometry. The measurements were performed after incubation for 48 hours in Ringer solution without or with gefitinib $(1-3 \mu \mathrm{g} / \mathrm{ml})$. As illustrated in Fig. 1B, a 48 hours exposure to gefitinib decreased the forward scatter, an effect reaching statistical significance at $2 \mu \mathrm{g} /$ ml gefitinib concentration.

Phosphatidylserine exposing erythrocytes were identified utilizing annexin-V-binding to phosphatidylserine, as determined by flow cytometry. Annexin-V-binding was analysed following an incubation of the erythrocytes for 48 hours in Ringer solution without or with 


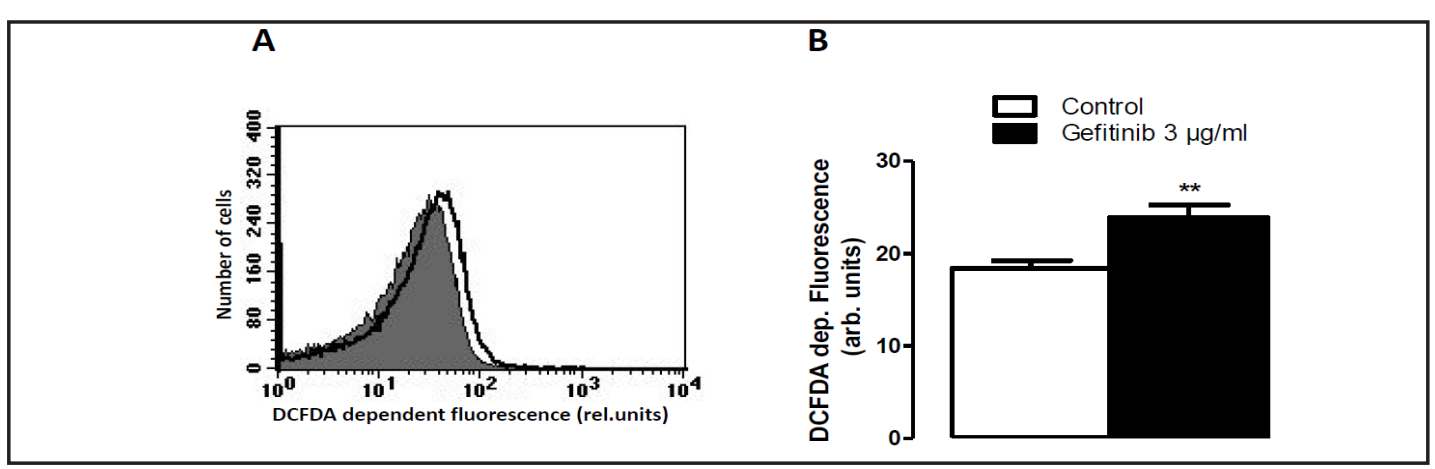

Fig. 4. Effect of gefitinib on reactive oxygen species. A. Original histogram of DCFDA fluorescence in erythrocytes following exposure for 48 hours to Ringer solution without (grey area) and with (black line) presence of $3 \mu \mathrm{g} / \mathrm{ml}$ gefitinib. B. Arithmetic means \pm SEM $(\mathrm{n}=14)$ of DCFDA fluorescence in erythrocytes following incubation for 48 hours to Ringer solution without (white bar) or with (black bar) gefitinib (3 $\mu \mathrm{g} / \mathrm{ml})$. ${ }^{* *}(\mathrm{p}<0.01)$ indicates significant difference from the absence of gefitinib (unpaired $t$ test).

gefitinib (1-3 $3 \mathrm{~g} / \mathrm{ml})$. As shown in Fig. 2, a 48 hours exposure to gefitinib increased the percentage of phosphatidylserine exposing erythrocytes, an effect again reaching statistical significance at $2 \mu \mathrm{g} / \mathrm{ml}$ gefitinib concentration.

Signaling in gefitinib induced cell membrane scrambling

Eryptosis could be triggered by increase of cytosolic $\mathrm{Ca}^{2+}$ activity $\left(\left[\mathrm{Ca}^{2+}\right]_{\mathrm{i}}\right)$. In order to quantify $\left[\mathrm{Ca}^{2+}\right]_{i}$, Fluo3 fluorescence was determined. The erythrocytes were analyzed after a 48 hours incubation in Ringer solution without or with gefitinib $(1-3 \mu \mathrm{g} / \mathrm{ml})$. As a result, the Fluo3 fluorescence was similar following exposure to $1 \mu \mathrm{g} / \mathrm{ml}$ gefitinib $(18.41 \pm 0.77$ a.u., $\mathrm{n}=$ 17), $2 \mu \mathrm{g} / \mathrm{ml}$ gefitinib (17.53 \pm 0.71 a.u., $\mathrm{n}=17)$, and $3 \mu \mathrm{g} / \mathrm{ml}$ gefitinib $(20.78 \pm 1.24$ a.u., $\mathrm{n}=$ $17)$ and following incubation in the absence of gefitinib (19.12 \pm 0.71 a.u., $n=17)$.

An additional series of experiments was performed to test whether gefitinib-induced translocation of phosphatidylserine to the erythrocyte surface was dependent on entry of extracellular $\mathrm{Ca}^{2+}$. To this end erythrocytes were incubated for 48 hours in the absence or presence of $3 \mu \mathrm{g} / \mathrm{ml}$ gefitinib in the presence or nominal absence of extracellular $\mathrm{Ca}^{2+}$. As illustrated in Fig. 3, removal of extracellular $\mathrm{Ca}^{2+}$ significantly blunted the effect of gefitinib on annexin-V-binding. On the other hand, gefitinib significantly increased the percentage of annexin-V-binding erythrocyte even in the absence of extracellular $\mathrm{Ca}^{2+}$. Accordingly, the gefitinib-induced cell membrane scrambling was partially, but not fully, dependent on the presence of extracellular $\mathrm{Ca}^{2+}$.

A further stimulator of eryptosis is oxidative stress. In order to test, whether gefitinib induces oxidative stress, reactive oxygen species (ROS) were quantified utilizing $2^{\prime}, 7^{\prime}$-dichlorodihydrofluorescein diacetate (DCFDA). As shown in Fig. 4, a 48 hours exposure to gefitinib $(3 \mu \mathrm{g} / \mathrm{ml})$ increased the DCFDA fluorescence of erythrocytes. Thus gefitinib did induce oxidative stress.

\section{Discussion}

The present observations reveal that gefitinib triggers eryptosis, the suicidal death of erythrocytes characterized by cell shrinkage and by cell membrane scrambling with phosphatidylserine translocation to the erythrocyte surface.

The effect of gefitinib on cell volume may be due to activation of $\mathrm{K}^{+}$channels, $\mathrm{K}^{+}$exit, cell membrane hyperpolarization, $\mathrm{Cl}^{-}$exit and thus cellular loss of $\mathrm{KCl}$ with water [50]. The lack of effect on cytosolic $\mathrm{Ca}^{2+}$ activity $\left(\left[\mathrm{Ca}^{2+}\right]_{\mathrm{i}}\right)$ is puzzling, as most triggers of eryptosis stimulate $\mathrm{Ca}^{2+}$ sensitive $\mathrm{K}^{+}$channels due to $\mathrm{Ca}^{2+}$ entry and subsequent increase of $\left[\mathrm{Ca}^{2+}\right]_{\mathrm{i}}[50]$. Possibly, the $\mathrm{K}^{+}$ channels are activated by gefitinib through mechanisms other than activation of $\mathrm{Ca}^{2+}$ entry, such as sensitization for cytosolic $\mathrm{Ca}^{2+}$. 
The effect of gefitinib on cell membrane scrambling was in large part dependent on the presence of $\mathrm{Ca}^{2+}$ in the extracellular space. Removal of extracellular $\mathrm{Ca}^{2+}$ significantly blunted the gefitinib induced eryptosis. Again, genfitinib may sensitize the cell membrane scrambling to cytosolic $\mathrm{Ca}^{2+}$. Gefitinib triggered cell membrane scrambling even in the nominal absence of extracellular $\mathrm{Ca}^{2+}$, an observation pointing to the involvement of additional mechanisms contributing to gefitinib induced cell membrane scrambling. As a matter of fact, gefitinib treatment significantly enhanced the abundance of reactive oxygen species, a well known trigger of eryptosis [50].

Phosphatidylserine exposing erythrocytes are recognized by phagocytosing cells, engulfed and thus rapidly cleared from circulating blood [50]. The clearance of eryptotic erythrocytes results in anemia as soon as the loss of erythrocytes surpasses the formation of new erythrocytes by erythropoiesis [50]. The gefitinib concentrations required for the stimulation of eryptosis are well in the range of concentrations $(1-2.2 \mu \mathrm{g} / \mathrm{ml})$ encountered in the plasma of patients receiving $2-3.5 \mathrm{mg}$ gefitinib once weekly [130]. The stimulation of eryptosis may thus well explain the anemia following gefitinib treatment.

The physiological purpose of eryptosis is the timely clearance of defective erythrocytes from circulating blood prior to hemolysis [50]. Failure to enter eryptosis may thus allow defective erythrocytes to undergo hemolysis with release of hemoglobin which may pass the renal glomerular filter, precipitate in the acidic lumen of renal tubules, occlude nephrons and thus lead to renal failure [131].

Stimulation of eryptosis may further compromise microcirculation [52, 132-136] by adherance of phosphatidylserine exposing erythrocytes to the vascular wall [137], as well as stimulation of blood clotting and thrombosis by phosphatidylserine exposing erythrocytes $[132,138,139]$.

In conclusion, gefitinib triggers erythrocyte cell membrane scrambling, an effect in part due to $\mathrm{Ca}^{2+}$ entry and oxidative stress. The effect could contribute to the development of anemia during gefitinib treatment of malignancy.

\section{Acknowledgements}

The authors acknowledge the meticulous preparation of the manuscript by Tanja Loch. The study was supported by the Deutsche Forschungsgemeinschaft and Open Access Publishing Fund of Tuebingen University.

\section{Disclosure Statement}

The authors declare no competing financial interests.

\section{References}

1 Sin TK, Wang F, Meng F, Wong SC, Cho WC, Siu PM, Chan LW, Yung BY: Implications of MicroRNAs in the Treatment of Gefitinib-Resistant Non-Small Cell Lung Cancer. Int J Mol Sci 2016;17:237.

$>2$ Biaoxue R, Shuanying Y, Wei L, Wei Z, Zongjuan M: Maintenance therapy of gefitinib for non-small-cell lung cancer after first-line chemotherapy regardless of epidermal growth factor receptor mutation: a review in Chinese patients. Curr Med Res Opin 2012;28:1699-1708.

3 Bogdanowicz BS, Hoch MA, Hartranft ME: Flipped script for gefitinib: A reapproved tyrosine kinase inhibitor for first-line treatment of epidermal growth factor receptor mutation positive metastatic nonsmall cell lung cancer. J Oncol Pharm Pract 2016;10.1177/1078155216634179.

-4 Cai L, Qiu X, Yang H, Lai M, Shan C, Hong W, Li J, Luo L, Zhang P, Wang L: Evaluation on efficacy and safety of the addition of X-knife therapy to gefitinib in NSCLC patients with symptomatic brain metastases. Oncotarget 2016;10.18632/oncotarget.10420 


\section{Cellular Physiology Cell Physiol Biochem 2017;41:1697-1708 \begin{tabular}{l|l|l|}
\hline DOI: 10.1159/000471823 & 2017 The Author(s). Published by S. Karger AG, Basel
\end{tabular} and BiOChemistry Published online: March 29, 2017 www.karger.com/cpb}

Al Mamun Bhuyan et al.: Gefitinib-Induced Eryptosis

5 Ferrazzi A, Russo I, Pasello G, Alaibac M: Atypical skin reaction in a patient treated with gefitinib for advanced lung cancer: A case report and review of the literature. Exp Ther Med 2016;11:197-200.

6 Hong D, Zhang G, Zhang X, Lian X: Pulmonary Toxicities of Gefitinib in Patients With Advanced Non-SmallCell Lung Cancer: A Meta-Analysis of Randomized Controlled Trials. Medicine (Baltimore) 2016;95:e3008.

7 Hsiue EH, Lee JH, Lin CC, Yang JC: Safety of gefitinib in non-small cell lung cancer treatment. Expert Opin Drug Saf 2016;15:993-1000.

-8 Kazandjian D, Blumenthal GM, Yuan W, He K, Keegan P, Pazdur R: FDA Approval of Gefitinib for the Treatment of Patients with Metastatic EGFR Mutation-Positive Non-Small Cell Lung Cancer. Clin Cancer Res 2016;22:1307-1312.

-9 Li MJ, He Q, Li M, Luo F, Guan YS: Role of gefitinib in the targeted treatment of non-small-cell lung cancer in Chinese patients. Onco Targets Ther 2016;9:1291-1302.

10 Nurwidya F, Takahashi F, Takahashi K: Gefitinib in the treatment of nonsmall cell lung cancer with activating epidermal growth factor receptor mutation. J Nat Sci Biol Med 2016;7:119-123.

11 Park K, Tan EH, O'Byrne K, Zhang L, Boyer M, Mok T, Hirsh V, Yang JC, Lee KH, Lu S, Shi Y, Kim SW, Laskin J, Kim DW, Arvis CD, Kolbeck K, Laurie SA, Tsai CM, Shahidi M, Kim M, Massey D, Zazulina V, Paz-Ares L: Afatinib versus gefitinib as first-line treatment of patients with EGFR mutation-positive non-small-cell lung cancer (LUX-Lung 7): a phase 2B, open-label, randomised controlled trial. Lancet Oncol 2016;17:577-589.

12 Sohn HS, Kwon JW, Shin S, Kim HS, Kim H: Effect of smoking status on progression-free and overall survival in non-small cell lung cancer patients receiving erlotinib or gefitinib: a meta-analysis. J Clin Pharm Ther 2015;40:661-671.

13 Wang F, Wang LD, Li B, Sheng ZX: Gefitinib compared with systemic chemotherapy as first-line treatment for chemotherapy-naive patients with advanced non-small cell lung cancer: a meta-analysis of randomised controlled trials. Clin Oncol (R Coll Radiol) 2012;24:396-401.

14 Zheng MH, Sun HT, Xu JG, Yang G, Huo LM, Zhang P, Tian JH, Yang KH: Combining Whole-Brain Radiotherapy with Gefitinib/Erlotinib for Brain Metastases from Non-Small-Cell Lung Cancer: A Meta-Analysis. Biomed Res Int 2016;2016:5807346.

15 Acharyya S, Sau S, Dasgupta P, Chakraborty A, Gangopadhyay S: Skin rash as a surrogate marker of clinical response of targeted therapy using gefitinib in advanced or metastatic non-small-cell lung cancer--a retrospective study. J Indian Med Assoc 2012;110:474-476, 493.

16 Araki T, Yashima H, Shimizu K, Aomori T, Hashita T, Kaira K, Nakamura T, Yamamoto K: Review of the treatment of non-small cell lung cancer with gefitinib. Clin Med Insights Oncol 2012;6:407-421.

17 Bronte G, Rolfo C, Giovannetti E, Cicero G, Pauwels P, Passiglia F, Castiglia M, Rizzo S, Vullo FL, Fiorentino E, Van Meerbeeck J, Russo A: Are erlotinib and gefitinib interchangeable, opposite or complementary for nonsmall cell lung cancer treatment? Biological, pharmacological and clinical aspects. Crit Rev Oncol Hematol 2014;89:300-313.

18 Chen MJ, Zhong W, Zhang L, Zhao J, Li LY, Wang MZ: Recurrence patterns of advanced non-small cell lung cancer treated with gefitinib. Chin Med J (Engl) 2013;126:2235-2241.

19 Chen X, Liu Y, Roe OD, Qian Y, Guo R, Zhu L, Yin Y, Shu Y: Gefitinib or erlotinib as maintenance therapy in patients with advanced stage non-small cell lung cancer: a systematic review. PLoS One 2013;8:e59314.

-20 Chen X, Pan Y, Zhang S, Chen D, Yang S, Li X, Ma S: Rechallenge with gefitinib following severe drug-induced hepatotoxicity in a patient with advanced non-small cell lung cancer: A case report and literature review. Oncol Lett 2014;7:878-880.

21 Dhillon S: Gefitinib: a review of its use in adults with advanced non-small cell lung cancer. Target Oncol 2015;10:153-170.

22 Ellis PM, Coakley N, Feld R, Kuruvilla S, Ung YC: Use of the epidermal growth factor receptor inhibitors gefitinib, erlotinib, afatinib, dacomitinib, and icotinib in the treatment of non-small-cell lung cancer: a systematic review. Curr Oncol 2015;22:e183-215.

23 Greenhalgh J, Bagust A, Boland A, Dwan K, Beale S, Hockenhull J, Proudlove C, Dundar Y, Richardson M, Dickson R, Mullard A, Marshall E: Erlotinib and gefitinib for treating non-small cell lung cancer that has progressed following prior chemotherapy (review of NICE technology appraisals 162 and 175): a systematic review and economic evaluation. Health Technol Assess 2015;19:1-134.

24 Kohler J, Schuler M: Afatinib, erlotinib and gefitinib in the first-line therapy of EGFR mutation-positive lung adenocarcinoma: a review. Onkologie 2013;36:510-518.

25 Luo C, Lv M, Li Y, Liu P, Yang J: Gefitinib-induced interstitial pneumonia: A case report and review of the literature. Exp Ther Med 2014;7:855-859. 


\section{Cellular Physiology Cell Physiol Biochem 2017;41:1697-1708 \begin{tabular}{l|l} 
and Biochemistry DOI: 10.1159/000471823 2017 & $\begin{array}{l}\text { (c) } 2017 \text { The Author(s). Published by S. Karger AG, Basel } \\
\text { www.karger.com/cpb }\end{array}$ \\
\hline
\end{tabular}}

Al Mamun Bhuyan et al.: Gefitinib-Induced Eryptosis

26 Marech I, Vacca A, Gnoni A, Silvestris N, Lorusso V: Surgical resection of locally advanced epidermal growth factor receptor (EGFR) mutated lung adenocarcinoma after gefitinib and review of the literature. Tumori 2013;99:e241-244.

-27 Passaro A, Alesini D, Pochesci A, Cortesi E: Erlotinib and gefitinib for elderly patients with advanced nonsmall-cell lung cancer. Anticancer Agents Med Chem 2014;14:646-650.

-28 Rahman AF, Korashy HM, Kassem MG: Gefitinib. Profiles Drug Subst Excip Relat Methodol 2014;39:239264.

29 Santelmo C, Ravaioli A, Barzotti E, Papi M, Poggi B, Drudi F, Mangianti M, Salvi M, Crino L: Coexistence of EGFR mutation and ALK translocation in NSCLC: literature review and case report of response to gefitinib. Lung Cancer 2013;81:294-296.

-30 Schuler M, Fischer JR, Grohe C, Gutz S, Thomas M, Kimmich M, Schneider CP, Laack E, Marten A: Experience with afatinib in patients with non-small cell lung cancer progressing after clinical benefit from gefitinib and erlotinib. Oncologist 2014;19:1100-1109.

31 Shi L, Tang J, Tong L, Liu Z: Risk of interstitial lung disease with gefitinib and erlotinib in advanced nonsmall cell lung cancer: a systematic review and meta-analysis of clinical trials. Lung Cancer 2014;83:231239.

-32 Singh N, Jindal A, Behera D: Erlotinib usage after prior treatment with gefitinib in advanced non-small cell lung cancer: A clinical perspective and review of published literature. World J Clin Oncol 2014;5:858-864.

-33 Tartarone A, Lazzari C, Lerose R, Conteduca V, Improta G, Zupa A, Bulotta A, Aieta M, Gregorc V: Mechanisms of resistance to EGFR tyrosine kinase inhibitors gefitinib/erlotinib and to ALK inhibitor crizotinib. Lung Cancer 2013;81:328-336.

34 Yuan Y, Li XF, Chen JQ, Dong CX, Weng SS, Huang JJ: Critical appraisal of the role of gefitinib in the management of locally advanced or metastatic non-small cell lung cancer. Onco Targets Ther 2014;7:841852.

-35 Zhou Q Cheng Y, Yang JJ, Zhao MF, Zhang L, Zhang XC, Chen ZH, Yan HH, Song Y, Chen JH, Feng WN, Xu CR, Wang Z, Chen HJ, Zhong WZ, Liu YP, Wu YL: Pemetrexed versus gefitinib as a second-line treatment in advanced nonsquamous nonsmall-cell lung cancer patients harboring wild-type EGFR (CTONG0806): a multicenter randomized trial. Ann Oncol 2014;25:2385-2391.

-36 Jalalat SZ, Cohen PR: Gefitinib-associated vitiligo: report in a man with parotid squamous cell carcinoma and review of drug-induced hypopigmentation. Dermatol Online J 2013;19:20020.

37 Li S, Zhang Z, Tang H, He Z, Gao Y, Ma W, Chang Y, Wei B, Ma J, Liu K, Ma Z, Wang Q: Pathological complete response to gefitinib in a 10-year-old boy with EGFR-negative pulmonary mucoepidermoid carcinoma: a case report and literature review. Clin Respir J 2015;10.1111/crj.12343

-38 Segovia-Mendoza M, Gonzalez-Gonzalez ME, Barrera D, Diaz L, Garcia-Becerra R: Efficacy and mechanism of action of the tyrosine kinase inhibitors gefitinib, lapatinib and neratinib in the treatment of HER2positive breast cancer: preclinical and clinical evidence. Am J Cancer Res 2015;5:2531-2561.

-39 Capmas P, Fernandez H: Effectiveness of gefitinib in combination with methotrexate in the treatment of ectopic pregnancy. Int J Womens Health 2015;7:673-676.

40 Cheng Y, Zhang Y, Zhang L, Ren X, Huber-Keener KJ, Liu X, Zhou L, Liao J, Keihack H, Yan L, Rubin E, Yang JM: MK-2206, a novel allosteric inhibitor of Akt, synergizes with gefitinib against malignant glioma via modulating both autophagy and apoptosis. Mol Cancer Ther 2012;11:154-164.

41 Rho JK, Choi YJ, Ryoo BY, Na, II, Yang SH, Kim CH, Lee JC: p53 enhances gefitinib-induced growth inhibition and apoptosis by regulation of Fas in non-small cell lung cancer. Cancer Res 2007;67:1163-1169.

42 Yar Saglam AS, Alp E, Elmazoglu Z, Menevse S: Treatment with cucurbitacin B alone and in combination with gefitinib induces cell cycle inhibition and apoptosis via EGFR and JAK/STAT pathway in human colorectal cancer cell lines. Hum Exp Toxicol 2016;35:526-543.

43 Zhao ZQ, Yu ZY, Li J, Ouyang XN: Gefitinib induces lung cancer cell autophagy and apoptosis via blockade of the PI3K/AKT/mTOR pathway. Oncol Lett 2016;12:63-68.

44 An C, Zhang J, Chu H, Gu C, Xiao F, Zhu F, Lu R, Shi H, Zhang H, Yi X: Study of Gefitinib and Pemetrexed as First-Line Treatment in Patients with Advanced Non-Small Cell Lung Cancer Harboring EGFR Mutation. Pathol Oncol Res 2016;22:763-768.

45 Burotto M, Manasanch EE, Wilkerson J, Fojo T: Gefitinib and erlotinib in metastatic non-small cell lung cancer: a meta-analysis of toxicity and efficacy of randomized clinical trials. Oncologist 2015;20:400-410. 


\section{Cellular Physiology Cell Physiol Biochem 2017;41:1697-1708

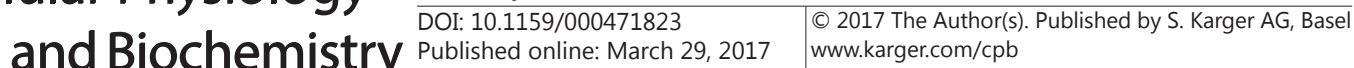

46 Daw NC, Furman WL, Stewart CF, Iacono LC, Krailo M, Bernstein ML, Dancey JE, Speights RA, Blaney SM, Croop JM, Reaman GH, Adamson PC: Phase I and pharmacokinetic study of gefitinib in children with refractory solid tumors: a Children's Oncology Group Study. J Clin Oncol 2005;23:6172-6180.

47 Kobayashi M, Matsui K, Katakami N, Takeda K, Moriyama A, Iwamoto Y, Takada M, Yoshioka H, Sueoka-Aragane N, Nakagawa K: Phase II study of gefitinib as a first-line therapy in elderly patients with pulmonary adenocarcinoma: West Japan Thoracic Oncology Group Study 0402. Jpn J Clin Oncol 2011;41:948-952.

48 Yoshimura N, Kudoh S, Mitsuoka S, Yoshimoto N, Oka T, Nakai T, Suzumira T, Matusura K, Tochino Y, Asai K, Kimura T, Kawaguchi T, Hirata K: Phase II study of a combination regimen of gefitinib and pemetrexed as first-line treatment in patients with advanced non-small cell lung cancer harboring a sensitive EGFR mutation. Lung Cancer 2015;90:65-70.

49 Yoshimura N, Okishio K, Mitsuoka S, Kimura T, Kawaguchi T, Kobayashi M, Hirashima T, Daga H, Takeda K, Hirata K, Kudoh S: Prospective assessment of continuation of erlotinib or gefitinib in patients with acquired resistance to erlotinib or gefitinib followed by the addition of pemetrexed. J Thorac Oncol 2013;8:96-101.

50 Lang E, Lang F: Mechanisms and pathophysiological significance of eryptosis, the suicidal erythrocyte death. Semin Cell Dev Biol 2015;39:35-42.

-51 Lang PA, Kaiser S, Myssina S, Wieder T, Lang F, Huber SM: Role of Ca2+-activated K+ channels in human erythrocyte apoptosis. Am J Physiol Cell Physiol 2003;285:C1553-C1560.

52 Abed M, Towhid ST, Mia S, Pakladok T, Alesutan I, Borst O, Gawaz M, Gulbins E, Lang F: Sphingomyelinaseinduced adhesion of eryptotic erythrocytes to endothelial cells. Am J Physiol Cell Physiol 2012;303:C991999.

53 Lau IP, Chen H, Wang J, Ong HC, Leung KC, Ho HP, Kong SK: In vitro effect of CTAB- and PEG-coated gold nanorods on the induction of eryptosis/erythroptosis in human erythrocytes. Nanotoxicology 2012;6:847856.

54 Maellaro E, Leoncini S, Moretti D, Del Bello B, Tanganelli I, De Felice C, Ciccoli L: Erythrocyte caspase-3 activation and oxidative imbalance in erythrocytes and in plasma of type 2 diabetic patients. Acta Diabetol 2013;50:489-495.

55 Bissinger R, Lang E, Ghashghaeinia M, Singh Y, Zelenak C, Fehrenbacher B, Honisch S, Chen H, Fakhri H, Umbach AT, Liu G, Rexhepaj R, Liu G, Schaller M, Mack AF, Lupescu A, Birnbaumer L, Lang F, Qadri SM: Blunted apoptosis of erythrocytes in mice deficient in the heterotrimeric G-protein subunit Galphai2. Sci Rep 2016;6:30925.

56 Lang E, Bissinger R, Fajol A, Salker MS, Singh Y, Zelenak C, Ghashghaeinia M, Gu S, Jilani K, Lupescu A, Reyskens KM, Ackermann TF, Foller M, Schleicher E, Sheffield WP, Arthur JS, Lang F, Qadri SM: Accelerated apoptotic death and in vivo turnover of erythrocytes in mice lacking functional mitogen- and stressactivated kinase MSK1/2. Sci Rep 2015;5:17316.

-57 Alzoubi K, Egler J, Abed M, Lang F: Enhanced Eryptosis Following Auranofin Exposure. Cell Physiol Biochem 2015;37:1018-1028.

58 Bissinger R, Barking S, Alzoubi K, Liu G, Liu G, Lang F: Stimulation of Suicidal Erythrocyte Death by the Antimalarial Drug Mefloquine. Cell Physiol Biochem 2015;36:1395-1405.

59 Bissinger R, Bouguerra G, Stockinger K, Abbes S, Lang F: Triggering of Suicidal Erythrocyte Death by Topotecan. Cell Physiol Biochem 2015;37:1607-1618.

60 Bouguerra G, Aljanadi O, Bissinger R, Abbes S, Lang F: Embelin-Induced Phosphatidylserine Translocation in the Erythrocyte Cell Membrane. Cell Physiol Biochem 2015;37:1629-1640.

61 Bouguerra G, Bissinger R, Abbes S, Lang F: Stimulation of Eryptosis by Narasin. Cell Physiol Biochem 2015;37:1807-1816.

62 Briglia M, Fazio A, Faggio C, Laufer S, Alzoubi K, Lang F: Triggering of Suicidal Erythrocyte Death by Ruxolitinib. Cell Physiol Biochem 2015;37:768-778.

63 Briglia M, Fazio A, Signoretto E, Faggio C, Lang F: Edelfosine Induced Suicidal Death of Human Erythrocytes. Cell Physiol Biochem 2015;37:2221-2230.

64 Calabro S, Alzoubi K, Faggio C, Laufer S, Lang F: Triggering of Suicidal Erythrocyte Death Following Boswellic Acid Exposure. Cell Physiol Biochem 2015;37:131-142.

65 Egler J, Lang F: Licochalcone A Induced Suicidal Death of Human Erythrocytes. Cell Physiol Biochem 2015;37:2060-2070. 


\section{Cellular Physiology Cell Physiol Biochem 2017;41:1697-1708 and Biochemistry Published online: March 29, $2017 \quad \begin{aligned} & \text { DOI: } 2017 \text { The Author(s). Published by S. Karger AG, Basel } \\ & \text { www.karger.com/cpb }\end{aligned}$ \\ Al Mamun Bhuyan et al.: Gefitinib-Induced Eryptosis}

66 Faggio C, Alzoubi K, Calabro S, Lang F: Stimulation of suicidal erythrocyte death by PRIMA-1. Cell Physiol Biochem 2015;35:529-540.

67 Fazio A, Briglia M, Faggio C, Alzoubi K, Lang F: Stimulation of Suicidal Erythrocyte Death by Garcinol. Cell Physiol Biochem 2015;37:805-815.

68 Lang E, Jilani K, Bissinger R, Rexhepaj R, Zelenak C, Lupescu A, Lang F, Qadri SM: Vitamin D-Rich Diet in Mice Modulates Erythrocyte Survival. Kidney Blood Press Res 2015;40:403-412.

-69 Lang E, Zelenak C, Eberhard M, Bissinger R, Rotte A, Ghashghaeinia M, Lupescu A, Lang F, Qadri SM: Impact of Cyclin-Dependent Kinase CDK4 Inhibition on Eryptosis. Cell Physiol Biochem 2015;37:1178-1186.

70 Officioso A, Alzoubi K, Manna C, Lang F: Clofazimine Induced Suicidal Death of Human Erythrocytes. Cell Physiol Biochem 2015;37:331-341.

71 Peter T, Bissinger R, Enkel S, Alzoubi K, Oswald G, Lang F: Programmed erythrocyte death following in vitro Treosulfan treatment. Cell Physiol Biochem 2015;35:1372-1380.

72 Stockinger K, Bissinger R, Bouguerra G, Abbes S, Lang F: Enhanced Eryptosis Following Exposure to Carnosic Acid. Cell Physiol Biochem 2015;37:1779-1791.

73 Waibel S, Bissinger R, Bouguerra G, Abbes S, Lang F: Saquinavir Induced Suicidal Death of Human Erythrocytes. Cell Physiol Biochem 2015;37:1973-1982.

-74 Zierle J, Bissinger R, Egler J, Lang F: Lapatinib Induced Suicidal Death of Human Erythrocytes. Cell Physiol Biochem 2015;37:2275-2287.

-75 Bissinger R, Bouguerra G, Al Mamun Bhuyan A, Waibel S, Abbes S, Lang F: Efavirenz Induced Suicidal Death of Human Erythrocytes. Cell Physiol Biochem 2015;37:2496-2507.

76 Bissinger R, Waibel S, Bouguerra G, Al Mamun Bhuyan A, Abbes S, Lang F: Enhanced Eryptosis Following Exposure to Lopinavir. Cell Physiol Biochem 2015;37:2486-2495.

77 Briglia M, Calabro S, Signoretto E, Alzoubi K, Laufer S, Faggio C, Lang F: Fucoxanthin Induced Suicidal Death of Human Erythrocytes. Cell Physiol Biochem 2015;37:2464-2475.

78 Briglia M, Fazio A, Faggio C, Lang F: Triggering of Suicidal Erythrocyte Death by Zosuquidar. Cell Physiol Biochem 2015;37:2355-2365.

-79 Fazio A, Briglia M, Faggio C, Alzoubi K, Lang F: Oxaliplatin Induced Suicidal Death of Human Erythrocytes. Cell Physiol Biochem 2015;37:2393-2404.

80 Macczak A, Cyrkler M, Bukowska B, Michalowicz J: Eryptosis-inducing activity of bisphenol A and its analogs in human red blood cells (in vitro study). J Hazard Mater 2016;307:328-335.

81 Officioso A, Alzoubi K, Lang F, Manna C: Hydroxytyrosol inhibits phosphatidylserine exposure and suicidal death induced by mercury in human erythrocytes: Possible involvement of the glutathione pathway. Food Chem Toxicol 2016;89:47-53.

82 Officioso A, Manna C, Alzoubi K, Lang F: Bromfenvinphos induced suicidal death of human erythrocytes. Pestic Biochem Physiol 2016;126:58-63.

-83 Qadri SM, Donkor DA, Bhakta V, Eltringham-Smith LJ, Dwivedi DJ, Moore JC, Pepler L, Ivetic N, Nazi I, Fox-Robichaud AE, Liaw PC, Sheffield WP: Phosphatidylserine externalization and procoagulant activation of erythrocytes induced by Pseudomonas aeruginosa virulence factor pyocyanin. J Cell Mol Med 2016;10.1111/jcmm.12778

84 Zierle J, Bissinger R, Bouguerra G, Abbes S, Lang F: Triggering of Suicidal Erythrocyte Death by Regorafenib. Cell Physiol Biochem 2016;38:160-172.

85 Pagano M, Faggio C: The use of erythrocyte fragility to assess xenobiotic cytotoxicity. Cell Biochem Funct 2015;33:351-355.

-86 Al Mamun Bhuyan A, Bissinger R, Stockinger K, Lang F: Stimulation of Suicidal Erythrocyte Death by Tafenoquine. Cell Physiol Biochem 2016;39:2464-2476.

-87 Al Mamun Bhuyan A, Signoretto E, Bissinger R, Lang F: Enhanced Eryptosis Following Exposure to Dolutegravir. Cell Physiol Biochem 2016;39:639-650.

-88 Al Mamun Bhuyan A, Signoretto E, Lang F: Triggering of Suicidal Erythrocyte Death by Psammaplin A. Cell Physiol Biochem 2016;39:908-918.

89 Almasry M, Jemaa M, Mischitelli M, Faggio C, Lang F: Stimulation of Suicidal Erythrocyte Death by Phosphatase Inhibitor Calyculin A. Cell Physiol Biochem 2016;40:163-171.

90 Bissinger R, Bhuyan AA, Signoretto E, Lang F: Stimulating Effect of Elvitegravir on Suicidal Erythrocyte Death. Cell Physiol Biochem 2016;38:1111-1120.

-91 Egler J, Zierle J, Lang F: Stimulating Effect of Manumycin A on Suicidal Erythrocyte Death. Cell Physiol Biochem 2016;38:1147-1156. 


\section{Cellular Physiology Cell Physiol Biochem 2017;41:1697-1708 and Biochemistry \begin{tabular}{l|l} 
DOI: 10.1159/000471823 & $\begin{array}{l}\text { (c) } 2017 \text { The Author(s). Published by S. Karger AG, Basel } \\
\text { www.karger.com/cpb }\end{array}$
\end{tabular}}

Al Mamun Bhuyan et al.: Gefitinib-Induced Eryptosis

92 Jemaa M, Mischitelli M, Fezai M, Almasry M, Faggio C, Lang F: Stimulation of Suicidal Erythrocyte Death by the CDC25 Inhibitor NSC-95397. Cell Physiol Biochem 2016;40:597-607.

$\$ 93$ Lang E, Pozdeev VI, Gatidis S, Qadri SM, Haussinger D, Kubitz R, Herebian D, Mayatepek E, Lang F, Lang KS, Lang PA: Bile Acid-Induced Suicidal Erythrocyte Death. Cell Physiol Biochem 2016;38:1500-1509.

$\$ 94$ Mischitelli M, Jemaa M, Almasry M, Faggio C, Lang F: Stimulation of Erythrocyte Cell Membrane Scrambling by Quinine. Cell Physiol Biochem 2016;40:657-667.

95 Mischitelli M, Jemaa M, Almasry M, Faggio C, Lang F: Stimulation of Suicidal Erythrocyte Death by Rottlerin. Cell Physiol Biochem 2016;40:558-566.

-96 Mischitelli M, Jemaa M, Almasry M, Faggio C, Lang F: Triggering of Erythrocyte Cell Membrane Scrambling by Emodin. Cell Physiol Biochem 2016;40:91-103.

97 Mischitelli M, Jemaa M, Almasry M, Faggio C, Lang F: Triggering of Suicidal Erythrocyte Death by Fascaplysin. Cell Physiol Biochem 2016;39:1638-1647.

-98 Mischitelli M, Jemaa M, Almasry M, Faggio C, Lang F: Ca2+ Entry, Oxidative Stress, Ceramide and Suicidal Erythrocyte Death Following Diosgenin Treatment. Cell Physiol Biochem 2016;39:1626-1637.

-99 Peter T, Bissinger R, Lang F: Stimulation of Eryptosis by Caspofungin. Cell Physiol Biochem 2016;39:939949.

100 Peter T, Bissinger R, Liu G, Lang F: Anidulafungin-Induced Suicidal Erythrocyte Death. Cell Physiol Biochem 2016;38:2272-2284.

101 Peter T, Bissinger R, Signoretto E, Mack AF, Lang F: Micafungin-Induced Suicidal Erythrocyte Death. Cell Physiol Biochem 2016;39:584-595.

102 Pretorius E, du Plooy JN, Bester J: A Comprehensive Review on Eryptosis. Cell Physiol Biochem 2016;39:1977-2000.

103 Shan F, Yang R, Ji T, Jiao F: Vitamin C Inhibits Aggravated Eryptosis by Hydrogen Peroxide in Glucose-6Phosphated Dehydrogenase Deficiency. Cell Physiol Biochem 2016;39:1453-1462.

104 Signoretto E, Bissinger R, Castagna M, Lang F: Stimulation of Eryptosis by Combretastatin A4 Phosphate Disodium (CA4P). Cell Physiol Biochem 2016;38:969-981.

105 Signoretto E, Castagna M, Al Mamun Bhuyan A, Lang F: Stimulating Effect of Terfenadine on Erythrocyte Cell Membrane Scrambling. Cell Physiol Biochem 2016;38:1425-1434.

106 Signoretto E, Castagna M, Lang F: Stimulation of Eryptosis, the Suicidal Erythrocyte Death by Piceatannol. Cell Physiol Biochem 2016;38:2300-2310.

107 Signoretto E, Honisch S, Briglia M, Faggio C, Castagna M, Lang F: Nocodazole Induced Suicidal Death of Human Erythrocytes. Cell Physiol Biochem 2016;38:379-392.

108 Signoretto E, Laufer SA, Lang F: Stimulating Effect of Sclareol on Suicidal Death of Human Erythrocytes. Cell Physiol Biochem 2016;39:554-564.

109 Signoretto E, Zierle J, Bissinger R, Castagna M, Bossi E, Lang F: Triggering of Suicidal Erythrocyte Death by Pazopanib. Cell Physiol Biochem 2016;38:926-938.

-110 Wesseling MC, Wagner-Britz L, Huppert H, Hanf B, Hertz L, Nguyen DB, Bernhardt I: Phosphatidylserine Exposure in Human Red Blood Cells Depending on Cell Age. Cell Physiol Biochem 2016;38:1376-1390.

-111 Zierle J, Bissinger R, Lang F: Inhibition by Teriflunomide of Erythrocyte Cell Membrane Scrambling Following Energy Depletion, Oxidative Stress and Ionomycin. Cell Physiol Biochem 2016;39:1877-1890.

112 Bissinger R, Modicano P, Alzoubi K, Honisch S, Faggio C, Abed M, Lang F: Effect of saponin on erythrocytes. Int J Hematol 2014;100:51-59.

113 Bissinger R, Modicano P, Frauenfeld L, Lang E, Jacobi J, Faggio C, Lang F: Estramustine-induced suicidal erythrocyte death. Cell Physiol Biochem 2013;32:1426-1436.

114 Lang E, Modicano P, Arnold M, Bissinger R, Faggio C, Abed M, Lang F: Effect of thioridazine on erythrocytes. Toxins (Basel) 2013;5:1918-1931.

115 Al Mamun Bhuyan A, Bissinger R, Cao H, Lang F: Triggering of Suicidal Erythrocyte Death by bexaroten. Cell Physiol Biochem 2016;in press.:

116 Abed M, Feger M, Alzoubi K, Pakladok T, Frauenfeld L, Geiger C, Towhid ST, Lang F: Sensitization of erythrocytes to suicidal erythrocyte death following water deprivation. Kidney Blood Press Res 2013;37:567-578.

117 Voelkl J, Alzoubi K, Mamar AK, Ahmed MS, Abed M, Lang F: Stimulation of suicidal erythrocyte death by increased extracellular phosphate concentrations. Kidney Blood Press Res 2013;38:42-51.

118 Abed M, Artunc F, Alzoubi K, Honisch S, Baumann D, Foller M, Lang F: Suicidal erythrocyte death in endstage renal disease. J Mol Med (Berl) 2014;92:871-879. 


\section{Cellular Physiology Cell Physiol Biochem 2017;41:1697-1708

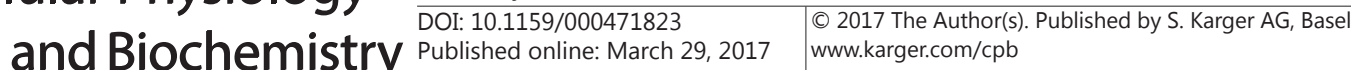

Al Mamun Bhuyan et al.: Gefitinib-Induced Eryptosis

119 Ahmed MS, Langer H, Abed M, Voelkl J, Lang F: The uremic toxin acrolein promotes suicidal erythrocyte death. Kidney Blood Press Res 2013;37:158-167.

120 Polak-Jonkisz D, Purzyc L: Ca(2+) influx versus efflux during eryptosis in uremic erythrocytes. Blood Purif 2012;34:209-210; author reply 210.

-121 Calderon-Salinas JV, Munoz-Reyes EG, Guerrero-Romero JF, Rodriguez-Moran M, Bracho-Riquelme RL, Carrera-Gracia MA, Quintanar-Escorza MA: Eryptosis and oxidative damage in type 2 diabetic mellitus patients with chronic kidney disease. Mol Cell Biochem 2011;357:171-179.

-122 Lang PA, Beringer O, Nicolay JP, Amon O, Kempe DS, Hermle T, Attanasio P, Akel A, Schafer R, Friedrich B, Risler T, Baur M, Olbricht CJ, Zimmerhackl LB, Zipfel PF, Wieder T, Lang F: Suicidal death of erythrocytes in recurrent hemolytic uremic syndrome. J Mol Med (Berl) 2006;84:378-388.

123 Nicolay JP, Schneider J, Niemoeller OM, Artunc F, Portero-Otin M, Haik G, Jr., Thornalley PJ, Schleicher E, Wieder T, Lang F: Stimulation of suicidal erythrocyte death by methylglyoxal. Cell Physiol Biochem 2006;18:223-232.

124 Bissinger R, Schumacher C, Qadri SM, Honisch S, Malik A, Gotz F, Kopp HG, Lang F: Enhanced eryptosis contributes to anemia in lung cancer patients. Oncotarget 2016;7:14002-14014.

125 Qadri SM, Mahmud H, Lang E, Gu S, Bobbala D, Zelenak C, Jilani K, Siegfried A, Foller M, Lang F: Enhanced suicidal erythrocyte death in mice carrying a loss-of-function mutation of the adenomatous polyposis coli gene. J Cell Mol Med 2012;16:1085-1093.

126 Bissinger R, Kempe-Teufel DS, Honisch S, Qadri SM, Randrianarisoa E, Haring HU, Henes J, Lang F: Stimulated Suicidal Erythrocyte Death in Arteritis. Cell Physiol Biochem 2016;39:1068-1077.

127 Lang PA, Schenck M, Nicolay JP, Becker JU, Kempe DS, Lupescu A, Koka S, Eisele K, Klarl BA, Rubben H, Schmid KW, Mann K, Hildenbrand S, Hefter H, Huber SM, Wieder T, Erhardt A, Haussinger D, Gulbins E, Lang F: Liver cell death and anemia in Wilson disease involve acid sphingomyelinase and ceramide. Nat Med 2007;13:164-170.

128 Lupescu A, Bissinger R, Goebel T, Salker MS, Alzoubi K, Liu G, Chirigiu L, Mack AF, Qadri SM, Lang F: Enhanced suicidal erythrocyte death contributing to anemia in the elderly. Cell Physiol Biochem 2015;36:773-783.

129 Lang E, Pozdeev VI, Xu HC, Shinde PV, Behnke K, Hamdam JM, Lehnert E, Scharf RE, Lang F, Haussinger D, Lang KS, Lang PA: Storage of Erythrocytes Induces Suicidal Erythrocyte Death. Cell Physiol Biochem 2016;39:668-676.

130 Gross ME, Leichman L, Lowe ES, Swaisland A, Agus DB: Safety and pharmacokinetics of high-dose gefitinib in patients with solid tumors: results of a phase I study. Cancer Chemother Pharmacol 2012;69:273-280.

131 Harrison HE, Bunting H, Ordway NK, Albrink WS: The Pathogenesis of the Renal Injury Produced in the Dog by Hemoglobin or Methemoglobin. J Exp Med 1947;86:339-356.

132 Andrews DA, Low PS: Role of red blood cells in thrombosis. Curr Opin Hematol 1999;6:76-82.

133 Closse C, Dachary-Prigent J, Boisseau MR: Phosphatidylserine-related adhesion of human erythrocytes to vascular endothelium. Br J Haematol 1999;107:300-302.

134 Gallagher PG, Chang SH, Rettig MP, Neely JE, Hillery CA, Smith BD, Low PS: Altered erythrocyte endothelial adherence and membrane phospholipid asymmetry in hereditary hydrocytosis. Blood 2003;101:46254627.

135 Pandolfi A, Di Pietro N, Sirolli V, Giardinelli A, Di Silvestre S, Amoroso L, Di Tomo P, Capani F, Consoli A, Bonomini M: Mechanisms of uremic erythrocyte-induced adhesion of human monocytes to cultured endothelial cells. J Cell Physiol 2007;213:699-709.

136 Wood BL, Gibson DF, Tait JF: Increased erythrocyte phosphatidylserine exposure in sickle cell disease: flowcytometric measurement and clinical associations. Blood 1996;88:1873-1880.

137 Borst O, Abed M, Alesutan I, Towhid ST, Qadri SM, Foller M, Gawaz M, Lang F: Dynamic adhesion of eryptotic erythrocytes to endothelial cells via CXCL16/SR-PSOX. Am J Physiol Cell Physiol 2012;302:C644-C651.

138 Chung SM, Bae ON, Lim KM, Noh JY, Lee MY, Jung YS, Chung JH: Lysophosphatidic acid induces thrombogenic activity through phosphatidylserine exposure and procoagulant microvesicle generation in human erythrocytes. Arterioscler Thromb Vasc Biol 2007;27:414-421.

139 Zwaal RF, Comfurius P, Bevers EM: Surface exposure of phosphatidylserine in pathological cells. Cell Mol Life Sci 2005;62:971-988. 